\title{
PENGARUH PEMBERIAN NATRIUM ALGINAT TERHADAP PENURUNAN KADAR KOLESTEROL TOTAL DARAH DAN BOBOT BADAN TIKUS
}

\author{
Thamrin Wikanta"), R. R. Nasution"'), dan Lestari Rahayu")
}

\begin{abstract}
ABSTRAK
Penelitian tentang pengaruh pemberian natrium alginat terhadap penurunan kadar kolesterol total darah dan bobot badan tikus telah dilakukan. Tikus putih galur Sprague dawley, jenis kelamin jantan, diberi makanan berkadar kolesterol tinggi dan minuman mengandung propil tiourasil 0,01\% untuk menjadikan kondisi hiperkolesterolemia. Kondisi hiperkolesterolemia dicapai setelah pemberian makanan berkadar kolesterol tinggi selama 3 minggu (21 hari). Bahan uji natrium alginat diberikan secara oral selama 4 minggu dengan tiga tingkat viskositas: $150 \mathrm{cps}$ (viskositas rendah), $300 \mathrm{cps}$ (viskositas sedang), dan $450 \mathrm{cps}$ (viskositas tinggi) dengan dosis sama besar $200 \mathrm{mg} / \mathrm{ekor} / \mathrm{hari}$ untuk semua viskositas. Pemberian natrium alginat dengan semua tingkat viskositas selama 4 minggu mampu menurunkan kadar kolesterol total darah secara efektif, tetapi tidak dapat menurunkan bobot badan tikus kecuali menggunakan alginat dengan viskositas $450 \mathrm{cps}$
\end{abstract}

ABSTRACT: Effect of sodium alginate feeding on the reduction of blood total cholesterol level and body weight of rat. By: Thamrin Wikanta, R. R. Nasution and Lestari Rahayu

Research on the effect of sodium alginate feeding on the reduction of total blood cholesterol level and body weight of rat has been done. Male white rats Sprague dawley, were given high cholesterol content feed and drink containing $0.01 \%$ propyl thiouracil to induce hypercholesterolemic condition. Hypercholesterolemic condition was gained after feeding high cholesterol content for 3 weeks (21 days). Sodium alginates were given orally for 4 weeks with three viscosity levels: $150 \mathrm{cps}$ (low viscosity), $300 \mathrm{cps}$ (medium viscosity), and $450 \mathrm{cps}$ (high viscosity) with the same dosage of $200 \mathrm{mg} / \mathrm{rat} / \mathrm{day}$ for all viscosity levels. Sodium alginate feeding with all viscosity levels for 4 weeks was able to reduce total blood cholesterol level effectively, but was not able to reduce rat body weight except by using alginate with the viscosity of $450 \mathrm{cps}$.

KEYWORDS: $\quad$ sodium alginate, total blood cholesterol level, body weight

\section{PENDAHULUAN}

Pada beberapa dasawarsa terakhir ini kadar kolesterol darah telah menjadi parameter untuk menentukan resiko penyakit jantung koroner. Dalam tubuh manusia, kolesterol merupakan prekursor hormon seks, hormon korteks adrenal, vitamin D dan garam empedu (Mayes, 1991; Heslet, 1997). Disamping itu, kolesterol juga merupakan konstituen membran sel, maka keberadaan kolesterol dalam tubuh sangat penting tetapi bila kadarnya terlalu tinggi dapat membahayakan kesehatan (Heslet, 1997). Kolesterol yang ada dalam tubuh manusia berasal dari makanan sehari-hari (eksogenik) dan hasil sintesis oleh tubuh (endogenik) (Guyton, 1987). Kolesterol eksogenik berasal dari bahan makanan yang berkalori tinggi dan mengandung asam lemak jenuh. Kolesterol endogenik disintesis oleh organ tubuh khususnya oleh hati hingga mencapai lebih dari $50 \%$ dari total kolesterol endogenik (Mayes, 1991;
Lewis, 1991).Kadar kolesterol dalam darah dipengaruhi oleh banyak faktor, di antaranya: usia, jenis kelamin, genetik, gaya hidup dan cara pemeriksaan

Kolesterol yang dikonsumsi akan dibawa oleh darah dalam bentuk lipoprotein bersama-sama dengan trigliserida, fosfolipida dan asam lemak bebas (Voet dan Voet, 1995). Lipoprotein dapat dibagi menjadi 5 macam, yaitu: kilomikron, VLDL (very low density lipoprotein), IDL (intermediate density lipoprotein), HDL (high density lipoprotein) dan LDL (low density lipoprotein). LDL (low density lipoprotein) disebut sebagai penyebab utama terjadinya arteriosklerosis karena LDL paling banyak mengandung kolesterol dibandingkan lipoprotein lain, dan LDL merupakan pengangkut kolesterol yang utama dalam darah. Selsel tubuh memerlukan kolesterol untuk pertumbuhan dan kolesterol tersebut didapatkan dari LDL melalui reseptor yang terdapat pada permukaan sel. Walaupun demikian jumlah kolesterol yang dapat

*) Peneliti pada Pusat Riset Pengolahan Produk dan Sosial Ekonomi Kelautan dan Perikanan

${ }^{\star \star}$ ) Fakultas Farmasi Universitas Pancasila 
diserap oleh sel adalah terbatas, maka orang yang banyak mengkonsumsi lemak jenuh akan memiliki kadar LDL yang tinggi dalam darahnya dan kadar kolesterol yang tinggi dalam selnya. Untuk mencegah penyerapan kolesterol lebih banyak, sel-sel mengurangi pembentukan reseptor LDL. Apabila kadar kolesterol dalam darah naik dengan pesat dapat meningkatkan kemungkinan terjadinya arteriosklerosis (Sokolow dan Mcllroy, 1979; Heslet, 1991).

Insiden penyakit jantung koroner di negara sedang berkembang lebih rendah dibandingkan dengan di negara yang sudah maju, hal ini dihubungkan antara lain dengan tingginya konsumsi lemak di negara yang sudah maju dari pada di negara yang sedang berkembang (Knight, 1995; Suyatna dan Handoko, 1995). Suatu penelitian di Framingham menunjukkan bahwa insiden penyakit jantung koroner paling tinggi jumlahnya pada kelompok masyarakat dengan kadar lemak dan lipoprotein plasma paling tinggi (Hegsted, 1991).

Pencegahan primer penyakit jantung koroner dapat dilakukan dengan olah raga secara teratur (Wenger, 1983) dan melakukan perubahan pola makan dengan mengurangi konsumsi lemak jenuh dan makanan berkalori tinggi serta menggantinya dengan makanan berkadar serat tinggi dan makanan yang mengandung asam lemak tidak jenuh. Terdapat dua jenis serat, yaitu serat yang larut dalam air dan serat yang tidak larut dalam air. Serat yang larut dalam air dapat menurunkan kadar kolesterol secara efektif karena serat akan mengikat asam dan garam empedu yang terdapat dalam sistem pencernaan yang berguna untuk mengemulsikan lemak, lalu membawanya ke luar tubuh bersama dengan tinja. Dengan demikian maka hati sebagai organ yang memproduksi asam empedu harus mengganti asam empedu yang hilang akibat diikat oleh serat. Untuk membentuk asam empedu maka hati memerlukan kolesterol. Kolesterol dalam darah akan disirkulasi ke hati lalu di dalam hati kolesterol diurai menjadi asam empedu. Berkat jasa serat, kolesterol disingkirkan dari tubuh bukannya tertimbun dalam arteri yang dapat menyebabkan terjadinya arteriosklerosis (Heslet, 1997).

Rumput laut atau alga telah lama digunakan oleh manusia baik untuk makanan (sebagai lalaban), kosmetik (sebagai pengemulsi, pengental) dan obatobatan (sebagai pengikat dan penghancur tablet pereduksi gula darah) (Suzuki et al., 1994; Wikanta 1996; Wikanta et al., 1998; Wikanta, 2000; Wikanta et al., 2000). Di Indonesia, meskipun tidak tercatat dalam literatur obat tradisional, masyarakat di wilayah pesisir sudah lama menggunakan beberapa jenis rumput laut sebagai obat. Pada umumnya rumput laut direbus dan air rebusan (dekokta) digunakan sebagai obat luar atau obat oral. Natrium alginat diekstraksi dari alga coklat. Berbagai spesies alga coklat telah lama digunakan sebagai obat, di antaranya adalah Sargassum siliquosum yang digunakan sebagai antipiretik. Selain itu Sargassum spp. juga memiliki kandungan zat yang dapat berfungsi sebagai antibakteri, antitumor, dan antihipertensi serta obat gangguan kelenjar tiroid dan gondok (Anggadiredja, 1992).

\section{BAHAN DAN METODE}

\section{Bahan Uji}

Bahan uji yang diteliti adalah natrium alginat hasil ekstraksi dari alga coklat Sargassum filipendula degan metoda Le Gloachech-Herter, masing-masing dengan kisaran viskositas $\left(2 \%, 25^{\circ} \mathrm{C}\right) 150 \mathrm{cps}$ (rendah), 300 cps (sedang), dan $450 \mathrm{cps}$ (tinggi). Larutan natrium alginat dengan konsentrasi $5 \%(50 \mathrm{mg} / \mathrm{ml})$, diberikan dengan dosis $200 \mathrm{mg} /$ ekor/hari atau $4 \mathrm{ml} /$ ekor/hari) menggunakan sonde lambung. Penentuan konsentrasi $5 \%$ berdasarkan atas pertimbangan apabila konsentrasi lebih dari 5\% maka larutan dengan viskositas $450 \mathrm{cps}$ akan sangat kental sehingga sukar diberikan menggunakan alat sonde lambung. Disamping itu, karena kapasitas lambung tikus sangat kecil maka volume larutan yang diberikan harus tidak lebih dari $5 \mathrm{ml}$, sehingga untuk mencapai dosis 200 $\mathrm{mg}$ hanya diperlukan volume $4 \mathrm{ml}$ /ekor/hari.

\section{Hewan Coba}

Hewan coba yang digunakan adalah tikus putih jantan, galur Sprague-dawley, umur 2-3 bulan, dan berbobot badan 160-180 gram, sebanyak 20 ekor yang diperoleh dari Pusat Penelitian Obat dan Makanan (PPOM), Jakarta.

\section{Makanan Standar Tikus}

Makanan standar tikus diperoleh dari Balai Pengujian Mutu dan Sertifikasi Obat Hewan, Gunung Sindur, Bogor. Makanan standar diberikan kepada hewan coba sebanyak 20 gram/ekor/hari.

\section{Makanan Tambahan}

Makanan tambahan diperlukan untuk meningkatkan kadar kolesterol darah tikus secara eksogen agar mencapai kondisi hiperkolesterolemia. Makanan tambahan dengan komposisi: kolesterol 1\%, kuning telur $5 \%$, lemak hewan $10 \%$, dan minyak goreng $1 \%$ dicampurkan ke dalam makanan standar hingga mencapai $100 \%$ (KKI, 1993). Kondisi hiperkolesterolemia pada tikus dapat dicapai dengan pemberian makanan tambahan berkadar kolesterol tinggi selama 21 hari ( 3 minggu). 


\section{Air Minum}

Air minum yang digunakan adalah air matang yang mengandung propil tiourasil $0,01 \%$ untuk meningkatkan kadar kolesterol secara endogen.

\section{Perlakuan Terhadap Hewan Coba}

Sebanyak 20 ekor tikus dibiarkan beradaptasi dengan lingkungan selama satu minggu dengan mendapatkan makanan standar dan minum air matang, kemudian dibagi menjadi empat kelompok dan diberi perlakuan seperti terlihat pada Tabel 1. Selama penelitian berlangsung dilakukan pengukuran kadar kolesterol total darah sebanyak 6 kali, yaitu pada awal percobaan (kadar kolesterol normal), saat tikus mencapai kondisi hiperkolesterolemia (setelah 3 minggu mendapat makanan tambahan), dan selama tikus mendapat sediaan uji natrium alginat dengan viskositas $150 \mathrm{cps}$ (rendah), $300 \mathrm{cps}$ (sedang), dan $450 \mathrm{cps}$ (tinggi) yaitu mulai minggu ke 4 hingga minggu ke 7

\section{Kadar Kolesterol Total Darah}

Sebelum pengambilan darah, tikus dipuasakan dahulu selama 6 jam. Darah sebanyak $2 \mathrm{ml}$ diambil dari bagian ekor, lalu disentrifugasi selama 10 menit dengan kecepatan 10.000 rpm. Lapisan yang jernih diambil dan diukur kadar kolesterolnya. Kadar kolesterol total darah diukur secara kolorimetri berdasarkan reaksi enzimatis menggunakan kit dari Hoffman la Roche, yang terdiri dari larutan kolesterol standar $200 \mathrm{mg} / \mathrm{dL}$, larutan buffer tris $0,15 \mathrm{M} \mathrm{pH} 7$ mengandung $\mathrm{p}$-khlorofenol $0,1 \%$, kolesterol oksidase $0,13 \mathrm{U} / \mathrm{ml}$, kolesterol ester hidrolase $0,13 \mathrm{U} / \mathrm{ml}$, peroksidase $2,4 \mathrm{U} / \mathrm{ml}$, dan 4 -amino antipirin 0,05\%.

\section{Analisis Data}

Data yang diperoleh dianalisis menggunakan metoda statistik analisis varian untuk melihat adanya perbedaan antar kelompok perlakuan dan apabila terdapat perbedaan bermakna (Fhit > Ftab pada $\alpha=$

Tabel 1. Perlakuan terhadap tikus selama percobaan.

Table 1. Treatments on the rats during experiment.

\begin{tabular}{|c|c|c|c|c|}
\hline Hari IDay & $\begin{array}{c}\text { Kelompok I } \\
\text { (kontrol negatif)/ } \\
\text { Group I } \\
\text { (negative control) }\end{array}$ & $\begin{array}{c}\text { Kelompok II/ } \\
\text { Group II }\end{array}$ & $\begin{array}{c}\text { Kelompok III/ } \\
\text { Group III }\end{array}$ & $\begin{array}{c}\text { Kelompok IVI } \\
\text { Group - IV }\end{array}$ \\
\hline 1 & $\begin{array}{l}\text { Makanan standar + air } \\
\text { matang. } \\
\text { Standard feed + boiled } \\
\text { water. }\end{array}$ & $\begin{array}{l}\text { Makanan standar + } \\
\text { air matang. } \\
\text { Standard feed + } \\
\text { boiled water. }\end{array}$ & $\begin{array}{l}\text { Makanan standar + } \\
\text { air matang. } \\
\text { Standard feed + } \\
\text { boiled water. }\end{array}$ & $\begin{array}{l}\text { Makanan standar + air } \\
\text { matang. } \\
\text { Standard feed + } \\
\text { boiled water. }\end{array}$ \\
\hline & $\begin{array}{l}\text { Makanan standar }+ \\
\text { makanan tambahan dan } \\
\text { air matang mengandung } \\
\text { propil tiourasil } 0,01 \% .\end{array}$ & $\begin{array}{l}\text { Makanan standar }+ \\
\text { makanan tambahan } \\
\text { dan air matang } \\
\text { mengandung propil } \\
\text { tiourasil } 0,01 \% \text {. }\end{array}$ & $\begin{array}{l}\text { Makanan standar }+ \\
\text { makanan tambahan } \\
\text { dan air matang } \\
\text { mengandung propil } \\
\text { tiourasil } 0,01 \% .\end{array}$ & $\begin{array}{l}\text { Makanan standar }+ \\
\text { makanan tambahan } \\
\text { dan air matang } \\
\text { mengandung propil } \\
\text { tiourasil } 0,01 \% \text {. }\end{array}$ \\
\hline & $\begin{array}{l}\text { Standard feed + } \\
\text { supplement feed and } \\
\text { boiled water contains } \\
\text { propyl thiouracil } 0.01 \% \text {. }\end{array}$ & $\begin{array}{l}\text { Standard feed + } \\
\text { supplement feed and } \\
\text { boiled water contains } \\
\text { propyl thiouracil } \\
0.01 \% \text {. }\end{array}$ & $\begin{array}{l}\text { Standard feed }+ \\
\text { supplement feed and } \\
\text { boiled water contains } \\
\text { propyl thiouracil } \\
0.01 \% \text {. }\end{array}$ & $\begin{array}{l}\text { Standard feed }+ \\
\text { supplement feed and } \\
\text { boiled water contains } \\
\text { propyl thiouracil } \\
0.01 \% \text {. }\end{array}$ \\
\hline \multirow{2}{*}{$23-51$} & $\begin{array}{l}\text { Makanan standar + air } \\
\text { matang. } \\
\text { Standard feed + boiled } \\
\text { water. }\end{array}$ & $\begin{array}{l}\text { Makanan standar + } \\
\text { air matang. } \\
\text { Na-alginat viskositas } \\
\text { rendah (150 cps). }\end{array}$ & $\begin{array}{l}\text { Makanan standar + } \\
\text { air matang. } \\
\text { Na-alginat viskositas } \\
\text { sedang ( } 300 \mathrm{cps} \text { ). }\end{array}$ & $\begin{array}{l}\text { Makanan standar + air } \\
\text { matang. } \\
\text { Na-alginat viskositas } \\
\text { tinggi ( } 450 \mathrm{cps} \text { ). }\end{array}$ \\
\hline & & $\begin{array}{l}\text { Standard feed + } \\
\text { boiled water and Na- } \\
\text { alginate with low } \\
\text { viscosity ( } 150 \mathrm{cps} \text { ). }\end{array}$ & $\begin{array}{l}\text { Standard feed + } \\
\text { boiled water and } \mathrm{Na}- \\
\text { alginate with medium } \\
\text { viscosity ( } 300 \mathrm{cps} \text { ). }\end{array}$ & $\begin{array}{l}\text { Standard feed + } \\
\text { boiled water and Na- } \\
\text { alginate with high } \\
\text { viscosity ( } 450 \text { cps). }\end{array}$ \\
\hline
\end{tabular}


0,05 dan 0,01) dilanjutkan dengan uji Tuckey untuk mengetahui kelompok perlakuan yang berbeda.

\section{HASIL DAN BAHASAN}

\section{Kadar Kolesterol Total Darah Tikus}

Hasil pengamatan menunjukkan bahwa kondisi hiperkolesterolemia dapat dicapai pada minggu ke 3 , dengan kadar kolesterol total darah tikus lebih dari $200 \mathrm{mg} / \mathrm{dL}$. Pengamatan selama tujuh minggu tentang kadar kolesterol total darah tikus putih jantan yang mengalami kondisi hiperkolesterolemia dengan perbedaan perlakuan dapat dilihat pada Gambar 1 (data pada Lampiran 1).

Analisis statistik terhadap data pengamatan kadar kolesterol total darah tikus pada setiap sampling menggunakan metoda analisis varian menunjukkan hasil sebagai berikut:

\section{a. Minggu ke-1 (kondisi awal atau hari ke-1).}

Fhit $(1,070)<\operatorname{Ftab}(3,24$ dan 5,29) berarti tidak ada perbedaan bermakna antar kelompok perlakuan atau kondisi awal tikus sama atau seragam dalam keadaan normal.

\section{b. Minggu ke-3 (kondisi hari ke-21).}

Fhit $(2,42)<$ Ftab $(3,24$ dan 5,29$)$ berarti tidak ada perbedaan bermakna antar kelompok perlakuan atau kondisi tikus pada setiap kelompok perlakuan dalam keadaan seragam mengalami kondisi hiperkolesterolemia pada tingkatan yang sama.

\section{c. Minggu ke-4 (kondisi hari ke-28).}

Fhit $(121,78)>F \operatorname{tab}(3,24$ dan 5,29) menunjukkan adanya perbedaan bermakna antar kelompok perlakuan maka dilanjutkan dengan uji Tukey untuk mengetahui kelompok mana yang berbeda. Hasil uji Tukey menunjukkan adanya perbedaan yang sangat nyata antara kelompok I (kontrol negatif) dengan kelompok II, III dan IV. Analisis Tukey menunjukkan telah terjadi penurunan kadar kolesterol total yang berarti pada kelompok II, III dan IV. Di samping itu, terdapat perbedaan sangat nyata antara kelompok II dengan kelompok IV yang berarti penurunan kadar kolesterol total pada kelompok IV (450 cps) dapat dikatakan lebih baik dari pada kelompok II (300 cps). Tidak ada perbedaan nyata antara kelompok II dengan III, yang artinya bahwa perbedaan viskositas $\mathrm{Na}$-alginat tidak menimbulkan perbedaan nyata pada kedua kelompok tersebut.

\section{d. Minggu ke-5 (kondisi hari ke-35).}

Fhit $(207,29)>F \operatorname{tab}(3,24$ dan 5,29) menunjukkan adanya perbedaan bermakna antar kelompok perlakuan maka dilanjutkan dengan uji Tukey untuk mengetahui kelompok mana yang berbeda. Hasil uj Tukey menunjukkan bahwa penurunan kadar kolesterol total darah tikus pada kelompok II, III, dan IV jauh lebih baik dari pada kelompok I (kontrol negatif)

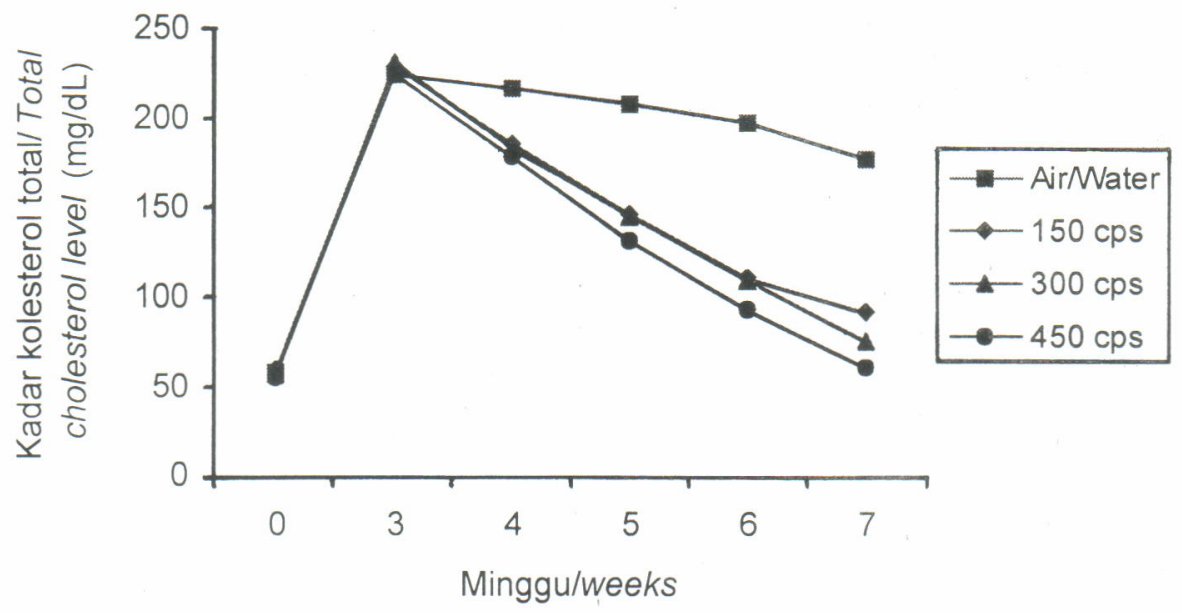

Gambar 1. Hubungan antara waktu pengamatan (minggu) dengan kadar kolesterol total darah tikus (mg/ $\mathrm{dL}$ ) setelah pemberian $\mathrm{Na}$-alginat dengan viskositas berbeda pada dosis sama.

Figure 1. The relationship between the time course of measurement (weeks) and the total rat blood cholesterol level ( $\mathrm{mg} / \mathrm{dL}$ ) after $\mathrm{Na}$-alginate feeding with different viscosities at the same dosage. 
sedangkan kelompok II tidak berbeda nyata dengan kelompok III berarti pada kedua kelompok tersebut tidak ada perbedaan dalam efek menurunkan kadar kolesterol total. Kelompok IV berbeda sangat nyata dengan kelompok II dan berbeda nyata dengan kelompok III yang berarti bahwa kelompok IV memberikan efek menurunkan kadar kolesterol total lebih baik dibandingkan dengan kelompok II dan III pada minggu ke-5.

\section{e. Minggu ke-6 (kondisi hari ke-42).}

Fhit $(207,29)>F \operatorname{tab}(3,24$ dan 5,29$)$ menunjukkan adanya perbedaan bermakna antar kelompok perlakuan maka dilanjutkan dengan uji Tukey untuk mengetahui kelompok mana yang berbeda. Hasil uji Tukey pada minggu ke-6 menunjukkan bahwa kelompok II, III, dan IV berbeda sangat nyata dengan kelompok I. Antara kelompok II dan III tidak ada perbedaan yang nyata sedangkan kelompok IV menunjukkan perbedaan yang sangat nyata dibandingkan dengan kelompok II dan III.

\section{f. Minggu ke-7 (kondisi hari ke-49).}

Fhit $(522,96)>F \operatorname{tab}(3,24$ dan 5,29$)$ menunjukkan adanya perbedaan bermakna antar kelompok perlakuan maka dilanjutkan dengan uji Tukey untuk mengetahui kelompok mana yang berbeda. Hasil uji Tukey pada minggu ke-7 menunjukkan bahwa kelompok IV mampu menurunkan kadar kolesterol total darah lebih baik dibandingkan kelompok lain. Antara kelompok II dan III baru menunjukkan perbedaan yang sangat nyata pada minggu ke-7.

Berbagai upaya banyak dilakukan untuk menurunkan kadar kolesterol darah melalui diet, baik dengan cara mengurangi makanan berkadar lemak tinggi maupun dengan menggunakan senyawa kimia "cholestyramine" dan "colestipol" (Rifkind, 1986). Untuk mengurangi atau menurunkan kadar kolesterol dalam darah dapat dilakukan dengan banyak mengkonsumsi makanan berserat seperti selulosa atau hemiselulosa. Mengkonsumsi makanan berserat, disamping bersifat non-toksik, cocok secara alamiah (biocompatible), mudah diurai mikroba secara alamiah, juga bernilai kalori negatif karena bersifat hipolipidemik. Adanya serat yang masuk ke dalam sistem pencernaan, mengakibatkan terjadinya pengikatan asam empedu oleh serat di dalam usus yang selanjutnya dibuang bersama dengan tinja. Sebagai akibat pengikatan asam empedu ini kadar asam empedu yang bersirkulasi di dalam hati akan menurun dan hal ini mendorong meningkatnya laju degradasi kolesterol menjadi asam empedu di dalam hati. Kerja hipokolesterolemik oleh serat dipengaruhi oleh tingginya laju degradasi kolesterol menjadi asam empedu karena terjadi penurunan kadar asam empedu yang bersirkulasi di dalam hati serta meningkatnya ekskresi asam empedu ke dalam tinja karena diserap oleh serat yang dikonsumsi (Pfeffer et al., 1981; Ebihara dan Schneeman, 1989; Indira dan Kurup, 1989). Kondisi tinja menjadi lunak karena sifat serat banyak menyerap air, yang akan mengakibatkan rendahnya tekanan di dalam usus besar. Proses ini akan mempersingkat waktu tertahannya tinja di dalam usus besar, sehingga dapat mencegah terjadinya gejala keram usus akibat iritasi (Ali et al., 1981).

\section{Bobot Badan Tikus}

Hasil pengamatan tentang pengaruh pemberian $\mathrm{Na}$-alginat terhadap perubahan bobot badan tikus dapat dilihat pada Gambar 2. Hasil analisis statistik terhadap data hasil pengamatan bobot badan tikus pada setiap minggu adalah sebagai berikut:

\section{a. Minggu ke-1 (kondisi awal atau hari ke-1).}

Fhit $(1,153)<F \operatorname{tab}(3,24$ dan 5,29$)$ menunjukkan tidak ada perbedaan bermakna antar kelompok perlakuan.

\section{b. Minggu ke-3 (kondisi hari ke-21).}

Fhit $(0,221)<F \operatorname{tab}(3,24$ dan 5,29$)$ berarti tidak ada perbedaan bermakna antar kelompok perlakuan, atau kondisi tikus pada setiap kelompok perlakuan ada dalam keadaan bobot badan yang seragam.

\section{c. Minggu ke-4 (kondisi hari ke-28).}

Fhit $(1,483)<F \operatorname{tab}(3,24$ dan 5,29) menunjukkan tidak ada perbedaan bermakna antar kelompok perlakuan.

\section{d. Minggu ke-5 (kondisi hari ke-35).}

Fhit $(6,39)>F \operatorname{tab}(3,24$ dan 5,29$)$ menunjukkan adanya perbedaan bermakna antar kelompok perlakuan, maka dilanjutkan dengan uji Tukey. Hasil uji Tukey menunjukkan adanya perbedaan yang sangat nyata antara kelompok IV dengan kelompok I (kontrol negatif) berarti telah terjadi penurunan bobot badan yang berarti pada kelompok IV dibandingkan dengan kelompok I.

\section{e. Minggu ke-6 (kondisi hari ke-42).}

Fhit $(6,331)>F \operatorname{tab}(3,24$ dan 5,29$)$ menunjukkan adanya perbedaan bermakna antar kelompok perlakuan, maka dilanjutkan dengan uji Tukey. Hasil uji Tukey menunjukkan adanya perbedaan yang sangat nyata antara kelompok IV dengan kelompok I (kontrol negatif) dan berbeda nyata antara kelompok IV dengan kelompok II dan III, berarti telah terjadi penurunan bobot 

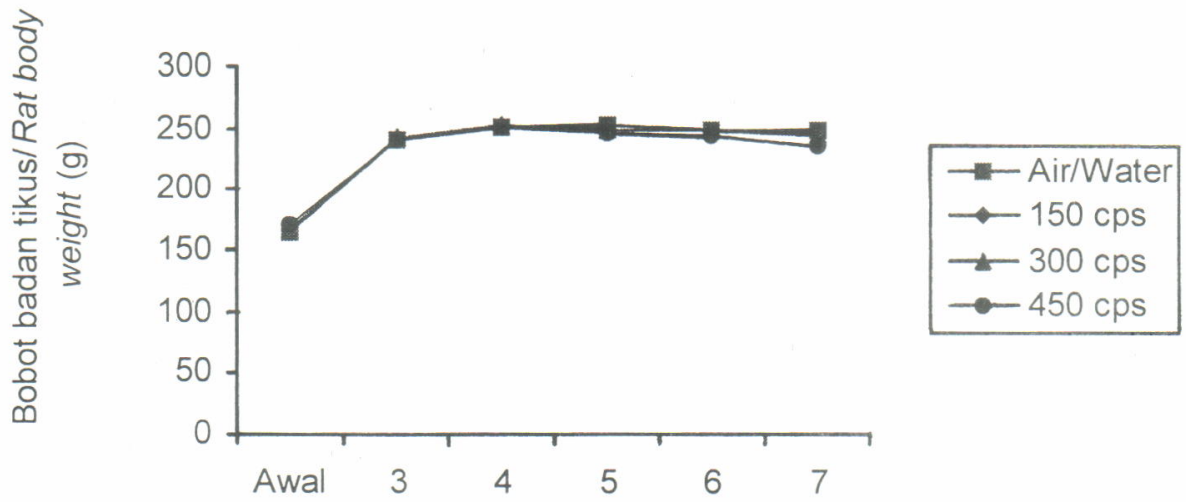

\section{Minggu/Weeks}

Gambar 2. Hubungan antara waktu pengamatan (minggu) dengan bobot badan tikus ( $\mathrm{g}$ ) setelah pemberian $\mathrm{Na}$-alginat dengan viskositas berbeda pada dosis sama.

Figure 2. The relationship between the time course of measurement (weeks) and the rat body weight (g) after $\mathrm{Na}$-alginate feeding with different viscosities at the same dosage.

badan yang berarti pada kelompok IV dibandingkan dengan kelompok I, II dan III:

\section{f. Minggu ke-7 (kondisi hari ke-49).}

Fhit $(11,95)>\operatorname{Ftab}(3,24$ dan 5,29) menunjukkan adanya perbedaan bermakna antar kelompok perlakuan, maka dilanjutkan dengan uji Tukey. Hasil uji Tukey menunjukkan adanya perbedaan yang sangat nyata antara kelompok IV dengan kelompok I (kontrol negatif), II, dan III, berarti telah terjadi penurunan bobot badan yang sangat berarti pada kelompok IV dibandingkan dengan kelompok I, II, dan III.

Natrium alginat merupakan senyawa serat yang mudah larut dalam air, membentuk larutan kental. Senyawa ini tidak dapat dicerna oleh cairan lambung dalam saluran cerna (Chapman dan Chapman, 1980; Anonym, 1990). Saat larut dalam air serat natrium alginat membentuk kisi-kisi seperti jala yang mampu mengikat kuat banyak molekul air dan menahan zat terlarut air dengan baik. Sifatnya sebagai emulgator semakin mempertinggi kemampuan pengikatan tersebut (King, 1983). Mekanisme serupa terjadi terhadap molekul lipid dan asam empedu yang berada dalam saluran cerna. Pengikatan atau penjeratan lipid oleh natrıum algınat menjadikan lipid dan kolesterol tidak dapat terabsorpsi tubuh melalui usus halus sehingga akhirnya keluar bersama tinja. Penyerapan lemak dan kolesterol eksogen oleh tubuh menjadi tercegah atau dapat terjadi tetapi sangat minimal. $\mathrm{Hal}$ ini terlihat pada Gambar 1, kadar kolesterol total dalam darah menurun tajam sejak tikus mengalami kondisi hiperkolesterolemia pada minggu ke-3 hingga pulih ke kondisi normal pada minggu ke-7. Keadaan tersebut terjadi, baik oleh penggunaan natrium alginat viskositas $450 \mathrm{cps}, 300 \mathrm{cps}$, maupun $150 \mathrm{cps}$, tetapi paling efektif dengan penggunaan natrium alginate viskositas $450 \mathrm{cps}$.

Asam empedu dalam keadaan normal mengikuti siklus enterohepatik sehingga tidak ikut keluar dari tubuh. Saat garam empedu terikat oleh natrium alginat maka dalam saluran cerna akan ikut terbawa keluar bersama tinja sehingga kadar asam empedu dalam tubuh menjadi berkurang. Untuk mengatasi hal itu maka tubuh mengubah cadangan kolesterol di dalam hati menjadi garam empedu sehingga mengakibatkan terjadinya penurunan kadar kolesterol hati secara bertahap. Penguraian cadangan kolesterol pada tikus yang menderita hiperkolesterolemia terlihat dengan terjadinya penurunan bobot badan yang nyata setelah mengkonsumsi natrium alginat hingga minggu ke- 7 . Penurunan bobot badan paling efektif terjadi pada kelompok IV yang mengkonsumsi natrium alginat dengan viskositas $450 \mathrm{cps}$ yaitu terjadi mulai minggu ke- 5 walaupun laju penurunan bobot badan tersebut relatif rendah.

\section{KESIMPULAN}

- Kondisi hiperkolesterolemia pada tikus dicapai setelah pemberian makanan tambahan yang berkadar kolesterol tinggi dan minuman yang mengandung propil tiourasil selama 3 minggu

- Pemberian natrium alginat viskositas $150 \mathrm{cps}$ dan $300 \mathrm{cps}$ pada tiga minggu pertama tidak mampu menurunkan kadar kolesterol total darah 
tikus secara nyata kecuali setelah pemberian minggu ke-4. Pemberian natrium alginat viskositas $450 \mathrm{cps}$ dosis $200 \mathrm{mg} / \mathrm{ekor} / \mathrm{hari}$ selama 4 minggu mampu menurunkan kadar kolesterol total darah tikus sampai pulih ke keadaan normal.

- Pemberian natrium alginat viskositas $150 \mathrm{cps}$ dan $300 \mathrm{cps}$ dosis $200 \mathrm{mg} / \mathrm{ekor} / \mathrm{hari}$ selama 4 minggu tidak mampu menurunkan bobot badan tikus kecuali dengan viskositas $450 \mathrm{cps}$.

- Pemberian natrium alginat mampu menurunkan kadar kolesterol total dalam darah secara efektif. Makin tinggi dosis atau viskositas yang diberikan makin tinggi efektifitasnya.

\section{SARAN}

- Perlu dilakukan penelitian lanjutan menggunakan variasi dosis yang lebih terinci agar diperoleh data yang lebih lengkap dan saling mendukung, dalam upaya penggunaan natrium alginat sebagai makanan suplemen penurun kolesterol total darah dan penurun bobot badan dalam kaitannya dengan program pelangsingan tubuh.

- Perlu dilakukan penelitian lanjutan tentang pengaruh pemberian natrium alginat terhadap kadar kolesterol-LDL, kolesterol-HDL, indeks arteriosklerosis, dll., dalam kaitannya dengan upaya penggunaan natrium alginat sebagai makanan suplemen.

\section{DAFTAR PUSTAKA}

Ali, R., H. Staub, G. Coccodrilli and L. Schanbacker, 1981. Nutritional significance of dietary fiber. Effect on nutrient bioavailability and selected gastrointestinal functions. J. Agric. Food Chem. 29: 465-472.

Anonym, 1990. Seaweed culture. YAMAHA Fishery Journal. Shizuoka-ken. No. 31. 8 pp.

Anggadiredja, J., 1992. Pemanfaatan sumber daya hayati laut makro-alga dalam industri farmasi (makanan dan obat-obatan). Buletin DRN No. 27. p. 31-36.

Bianchini, F., Caderni, G., Dolara, P., Fanteti, L. dan Kriebel, 1989. Effect of dietary fat, starch and cellulose on fecal bile acid in mice. J. Nutr. 119 (1):

Chapman V.J. and D.J. Chapman, 1980, Seaweeds and Their Uses. Third editon. Chapman and Hall, London. p. 194-225

Ebihara, K. and O. Schneeman, 1989. Interaction of bile acids, phospholipids, cholesterol and triglyceride with dietary fibers in the small intestine of rats. J. Nutr. 116 (8): $1.100-1.106$

Guyton, A. C., 1987. Fisiologi Manusia dan Mekanisme Penyakit. Edisi III. Alih bahasa: P. Adrianto, EGC., Jakarta. p. 623-630.

Hegsted, D.M. 1991. Dietary Fatty Acids, Serum Cholesterol and Coronary Heart Disease. In Nelson, G.J.
(Ed.). Health Effects of Dietary Fatty Acids American Oil Chemists' Society. Champaign, Ilionis. p. 50-68.

Heslet, L. 1997. Kolesterol. Alih bahasa: A. Aiwiyanto. Kesaint Blanc. Jakarta. $81 \mathrm{pp}$.

Indira, M. and Kurup, P. A. 1989. Effects of neutral detergent fiber from blackgram (Phaseolus mungo) in rats and rabbits. J. Nutr. 119 (9): 1246-1251.

KKI. 1993. Penapisan Farmakologi, Pengujian Fitokimia dan Pengujian Klinik. Yayasan Pengembangan Obat, Bahan Alam, Phytomedica, Jakarta. p. 37-39.

King, A.H. 1983. Brown Seaweed Extracts (Alginates). In Glicksman (Ed.). Food Hydrocolloids. Vol. II. CRC Press, Inc., Florida. p. 115-188.

Knight, J.F. 1995. Jantung Kuat, Bernafas Lega. Alih bahasa: Panjaitan, M. dan Lina Limanto. Indonesia Publishing House. Bandung. p. 30-45.

Lewis, J.B. 1991. Disorder of Lipid Transport. In Weatherall, D.J., Ledingham, J.G.G., Warrel,D.A. (Eds.). Oxford Textbook of Medicine. Vol. I, Oxford University Pres, Oxford. p. 958-968.

Mayes, P. A. 1991. Cholesterol Synthesis, Transport and Excretion. In Murray, R., Granner, D.K., Mayes P.A. dan Rodwell, V. W. (Eds.). Harper's Biochemistry. Ed. 22. Prentice Hall International Inc., p. 249-260.

Patel, C. 1998. Petunjuk Praktis Mencegah dan Mengobati Penyakit Jantung. Alih bahasa: A. T. Widodo. Gramedia Pustaka Utama, Jakarta. 279 p.

Petch, M. 1991. Penyakit Jantung. Alih bahasa: Gunadi. Arcan, Jakarta. 135 pp.

Pfeffer, P.E., Doner, L.W., Hoagland, P.D. and McDonald, G.G. 1981. Molecular interactions with dietary fiber components. Investigation of the possible association of pectin and bile acids. J. Agric. Food Chem. 29: 455-461.

Rifkind, B. M. 1986. Diet, plasma cholesterol and coronary heart disease. J. Nutr. 116 (8): 1.578-1.580.

Sokolow, M. dan M. B. Mcllroy, 1979. Clinical Cardiology. Lange. p. 124-132.

Suyatna, F.D. dan Handoko, T. 1995. Hipolipidemik. In Sulistia, G. (Ed.). Farmakologi dan Terapi. Ed. IV. Bag. Farmakologi FKUI, Jakarta. p. 364-368.

Suzuki, T., Nahai, K., Yoshie, Y., Shirai, T. dan Hirono, T. 1994. Effect of sodium alginates on mineral absorption and blood sugar of rats. J. Tokyo Univ. of Fish., 81(2):93-99.

Voet, D. and Voet, J.G. 1995. Biochemistry: Lipid Metabolism. Sec. Ed. John Wiley \& Sons, Inc., New York. p. 663- 726.

Wade, A. dan Weller, P. J. 1994. Handbook of Pharmaceutical Excipients. The Pharmaceutical Press, London. p. 428-429.

Wenger, N. K., 1983. Physical Activity and Modification of Coronary Risk. In Pyorala, K., Rapaport, E., Konig, K., Schettler, G. dan Diehm, C. (Eds.). Secondary Prevention of Coronary Heart Disease. Thieme-Stration Inc., New York. p. 56-61.

Wikanta, T. 1996. Prospek pengembangan dan pemanfaatan rumput laut (Phaeophyceae) di Indonesia sebagai sumber senyawa alginat. J. Litbang Pertanian, Jakarta. p. 16-20. 
Wikanta, T., Rejeki, D.S. dan Rahayu, L. 1998. The content and physico-chemical characteristics of alginate extracted from three species of brown algae ( $S$. cinereum, $H$. triquetra and $T$. conoides). Ind. Fish. Res. J., CRIFI, Jakarta. 4 (1): 46-50,

Wikanta, T., 2000. Ekstrak Alginat dari Alga Coklat dan Pemanfaatannya dalam Industri dan Kesehatan. Dipresentasikan pada Seminar Sehari: Pemanfaatan Bahan Alam Bahari Sebagai Sediaan Farmasi Dan Kosmetik. Program Profesi Apoteker Fakultas Farmasi Universitas 17 Agustus 1945. Jakarta, 4 Nopember 2000. 16 pp.
Wikanta, T., Riyadi, A. dan Rahayu, L. 2000. Pengaruh pemberian natrium alginat terhadap penurunan kadar glukosa darah kelinci dengan metoda toleransi glukosa oral. J. Octopus. Networking on Marine Fisheries and Environment, Jakarta. 4(1) $1-13$

Wissler, R.W., 1989. Principles of Pathogenesis of Atherosclerosis. In Eugene Braunswald (Ed.). Heart Disease. W. B. Saunders Co., Philadelphia. p. 1.2211.271 . 
Lampiran 1. Rata-rata kadar kolesterol total darah tikus pada berbagai perlakuan selama percobaan. Appendix 1. Mean total cholesterol levels of the blood rat on each treatment during experiment.

\begin{tabular}{cccccrc}
\hline \multicolumn{7}{c}{$\begin{array}{c}\text { Kadar Kolesterol Total Darah (mg/dL + SD) } \\
\text { Blood Total Cholesterol Level (mg/dL + SD) }\end{array}$} \\
\hline $\begin{array}{c}\text { Minggu ke } \\
\text { Weeks }\end{array}$ & $\begin{array}{c}\text { Hari ke } \\
\text { Days }\end{array}$ & $\begin{array}{c}\text { Kelompok - I } \\
\text { Group - I } \\
\text { (air/water) }\end{array}$ & $\begin{array}{c}\text { Kelompok - II } \\
\text { Group - II } \\
(\mathbf{1 5 0} \mathbf{c p s )}\end{array}$ & $\begin{array}{c}\text { Kelompok - III } \\
\text { Group - III } \\
(\mathbf{3 0 0} \mathbf{c p s )}\end{array}$ & $\begin{array}{c}\text { Kelompok - IV } \\
\text { Group - IV } \\
(\mathbf{4 5 0} \mathrm{cps)}\end{array}$ \\
\hline 0 & Awal/early & $58.6 \pm 4.615$ & $60.2 \pm 4.382$ & $56.8 \pm 4.438$ & $55.8 \pm 3.271$ \\
3 & 21 & $225.6 \pm 4.227$ & $229.2 \pm 5.630$ & $232.4 \pm 3.647$ & $225.0 \pm 5.873$ \\
4 & 28 & $217.8 \pm 1.923$ & $187.0 \pm 3.535$ & $183.6 \pm 4.393$ & $178.8 \pm 3.962$ \\
5 & 35 & $209.2 \pm 2.588$ & $146.6 \pm 7.197$ & $145.0 \pm 5.787$ & $133.0 \pm 4.690$ \\
6 & 42 & $198.4 \pm 2.702$ & $111.4 \pm 5.458$ & $109.8 \pm 6.797$ & $93.8 \pm 4.438$ \\
7 & 49 & $178.2 \pm 2.863$ & $92.4 \pm 3.209$ & $76.2 \pm 7.293$ & $61.2 \pm 5.761$ \\
\hline
\end{tabular}

